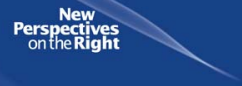

\title{
David Cameron
}

and Conservative

renewal

The limits of modernisation?

EDITED BY

GILLIAN PEELE AND JOHN FRANCIS

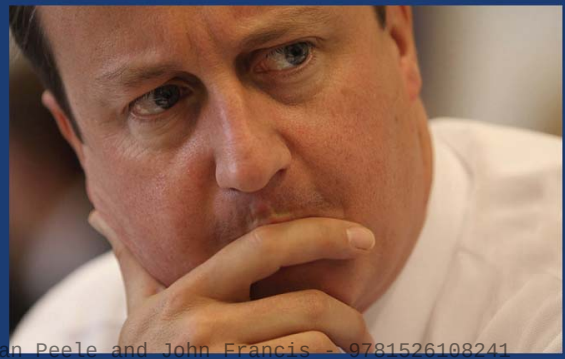




\section{David Cameron and Conservative renewal}

\section{MANCHESTER 1824}

Manchester University Press 


\section{New \\ Perspectives}

Series editor

Richard Hayton

The study of conservative politics, broadly defined, is of enduring scholarly interest and importance, and is also of great significance beyond the academy. In spite of this, for a variety of reasons the study of conservatism and conservative politics was traditionally regarded as something of a poor relation in comparison to the intellectual interest in 'the Left'. In the British context this changed with the emergence of Thatcherism, which prompted a greater critical focus on the Conservative Party and its ideology, and a revitalisation of Conservative historiography. New Perspectives on the Right aims to build on this legacy by establishing a series identity for work in this field. It will publish the best and most innovative titles drawn from the fields of sociology, history, cultural studies and political science and hopes to stimulate debate and interest across disciplinary boundaries. New Perspectives is not limited in its historical coverage or geographical scope, but is united by its concern to critically interrogate and better understand the history, development, intellectual basis and impact of the Right. Nor is the series restricted by its methodological approach: it will encourage original research from a plurality of perspectives. Consequently, the series will act as a voice and forum for work by scholars engaging with the politics of the right in new and imaginative ways.

Reconstructing conservatism? The Conservative party in opposition, 1997-2010

Richard Hayton

Conservative orators from Baldwin to Cameron

Edited by Richard Hayton and Andrew S. Crines

The right and the recession

Edward Ashbee

The territorial Conservative Party: Devolution and party change in Scotland and Wales

Alan Convery 


\title{
David Cameron and Conservative renewal \\ The limits of modernisation?
}

\author{
Edited by \\ Gillian Peele and John Francis
}

Manchester University Press 
While copyright in the volume as a whole is vested in Manchester University Press, copyright in individual chapters belongs to their respective authors, and no chapter may be reproduced wholly or in part without the express permission in writing of both author and publisher.

Published by Manchester University Press

Altrincham Street, Manchester M1 7JA, UK

www.manchesteruniversitypress.co.uk

British Library Cataloguing-in-Publication Data

A catalogue record for this book is available from the British Library

Library of Congress Cataloging-in-Publication Data applied for

ISBN 9781784991531 hardback

First published 2016

The publisher has no responsibility for the persistence or accuracy of URLs for any external or third-party internet websites referred to in this book, and does not guarantee that any content on such websites is, or will remain, accurate or appropriate

Typeset in Arno Pro by

Servis Filmsetting Ltd, Stockport, Cheshire 